\title{
Public Programs for Essential Medicine Access in a Small Municipality: A Cross-Sectional Analysis
}

\author{
Zeó Jaime Lacerda Chaves, ${ }^{1 \oplus}$ Luiz Sérgio Silva, ${ }^{\circledR \oplus}$ Renata Cristina Rezende Macedo do Nascimento ${ }^{3 \oplus}$ \\ Universidade Federal de Viçosa,' Viçosa, MG - Brazil \\ Universidade Federal de Minas Gerais, ${ }^{2}$ Belo Horizonte, MG - Brazil \\ Universidade Federal de Ouro Preto, ${ }^{3}$ Ouro Preto, MG - Brazil
}

\section{Abstract}

Background: Public programs that provide access to essential medications have played an important role in the care of hypertensive and diabetic patients. However, access in small municipalities has been poorly studied.

Objective: To describe the sociodemographic profile and the medication and health service usage of patients with systemic arterial hypertension and/or diabetes mellitus in a small municipality who use the public medication access programs Health has no Price (Saúde Não Tem Preço - SNTP) and the Minas Pharmacy Network.

Methods: This cross-sectional study with 341 participants was conducted in 2019. Home interviews were conducted using a standardized, semi-structured questionnaire. The data are expressed as absolute and relative frequencies, and Pearson's chi-square test was used for comparisons between proportions $(\alpha=5 \%)$.

Results: Most of the participants (70.68\%) had hypertension only, $11.14 \%$ had diabetes only, and $18.18 \%$ had both. Regarding the origin of the hypertension medications, $82.67 \%$ were provided by the Minas Pharmacy Network and/or SNTP programs. Regarding oral hypoglycemic agents and insulins, $88.61 \%$ were provided by the Minas Pharmacy Network and/or SNTP. Most participants were female (63.1\%), at least 65 years of age (50.30\%), nonWhite $(66.96 \%)$, resided in an urban area (67.16\%), were illiterate or had a low education level (89.94\%), and had a maximum income $\leq 2$ times the federal minimum salary $(89.19 \%)$. Overall user perception was significantly better for SNTP $(\mathrm{p}=0.010)$.

Conclusion: The results of this study indicate that programs which provide access to essential medications are important sources of hypertension and diabetes medications in the study area, especially for people with low incomes.

Keywords: Access to Essential Medicines and Health Technologies; Drugs, Essential; National Drug Policy; Pharmaceutical Services; Hypertension; Diabetes Mellitus.

\section{Introduction}

Chronic non-communicable diseases (CNCDs) are a public health problem and one of the main causes of morbidity and mortality in Brazil and around the world. ${ }^{1}$ In 2015 , there were approximately 1.13 billion adults with systemic arterial hypertension (SAH) worldwide, and this number is expected to reach 1.6 billion by $2025 .^{2-4}$ In 2017, the International Diabetes Federation estimated that $8.8 \%$ (ranging from: 7.2 to 11.3 ) of the world's population, ie, 424.9 million people between 20 and 79 years old, have diabetes mellitus (DM). 5,6

One important factor for the increased prevalence of CNCDs in Brazil is the recent aging of the population. This requires health actions, including the adequate provision of medications. ${ }^{7,8}$ Drug therapy, which is necessary to control and prevent acute and chronic complications of SAH and DM, leads to lower morbidity and mortality and increased quality of life. Thus, ensuring access to medication has become a fundamental strategy in Brazilian public health policies. ${ }^{9}$

Mailing Address: Zeó Jaime Lacerda Chaves

Av. Peter Henry Rolfs, s/n. Postal Code: 36570-900, Campus Universitário, Viçosa, MG - Brazil.

E-mail: zeojaime@yahoo.com.br 
To guarantee access to essential medications in primary care, we highlight two programs that have been structured according to the guidelines of the National Medication Policy and the National Pharmaceutical Assistance Policy: the federal program Health Has No Price (Saúde Não Tem Preço - SNTP) and the Minas Gerais State Pharmacy Network (Rede Farmácia de Minas - RFM). ${ }^{10}$

Established in 2004, the Brazilian Popular Pharmacy Program was initially designed as a distinct network of pharmacies. In these pharmacies, users could purchase medications with discounts of up to $90 \%$ off their market value. This phase of the network was in force until 2017. ${ }^{11,12}$ By 2006, the program was expanded to include partnerships with private enterprise: in drugstores designated "People's Pharmacies" ("Aqui Tem Farmácia Popular") all medications could be obtained through copayment. ${ }^{11}$ In 2011, the program was again restructured with the launch of SNTP: partner drugstores began providing free $\mathrm{SAH}$ and DM medications and, later, asthma mdications. ${ }^{13,14}$ The RFM was developed by the Minas Gerais state government in 2008 to ensure the regular and free supply of basic medications through Unified Health System health care units. ${ }^{7}$

These programs have been playing a relevant role in the care of hypertensive and diabetic patients, especially among socially vulnerable patients, for whom free medications are the only treatment alternative. ${ }^{15}$ However, according to Nascimento et al. ${ }^{16}$ despite the fact that access to medications is considered a legal right, distribution can still be low and should be evaluated from the perspective of availability, geographic accessibility, acceptability, and purchasing power. Furthermore, the profile of SNTP and RFM users and their medication use can be influenced by the demographic structure, socioeconomic, behavioral, and cultural factors, the morbidity profile, the characteristics of the pharmaceutical market, and targeted government policies for the Sector. ${ }^{17}$ Identifying the profile of public access program users is essential for determining the factors that influence how the population obtains medications, which can guide government interventions.

In this context, it should be pointed out that studies on medication access in small rural municipalities with rural characteristics are rare. The municipality in which this study was conducted, which is located in the Zona da Mata region of the state of Minas Gerais, is characterized by the Brazilian Institute of Geography and Statistics (IBGE) as an rural-adjacent area, since most of its activities are linked to the countryside, such as coffee and bean cultivation, swine and cattle farming, and family farms. Given the importance of medication access and the need to better understand the dynamics involved, studies in rural populations are essential for monitoring and evaluating public pharmaceutical assistance policies. According to our literature review, no such study has ever been conducted in this region. ${ }^{18,19}$

Thus, this study aimed to describe the sociodemographics, medication use, and health service profile of patients with SAH and/or DM who use the SNTP and RFM programs for access to essential medications in this small municipality in Minas Gerais, Brazil.

\section{Methodology}

A cross-sectional epidemiological study was conducted through a household survey of patients with hypertension and/or diabetes who used the SNTP and RFM programs for access to medication. The study took place in the urban and rural areas of a small municipality whose population, according to the 2010 census, is 12,848 inhabitants, $56.76 \%$ of whom live in the urban area. The municipality has 5 Family Health Strategy teams, 6 drugstores accredited by the SNTP program, and 1 RFM unit. ${ }^{18}$

The study included hypertensive and/or diabetic patients (of either sex and aged 18 years or older) who continuously used some antihypertensive and/or oral hypoglycemic medication and/or insulin and who used the SNTP and/or RFM programs for medication access. Sample calculation considered the total number of inhabitants of the municipality and the SAH prevalence (32.5\%), which was higher than DM. ${ }^{4}$ The sample size was calculated using Epi Info version 3, as described in the following equation:

$$
n=\frac{[E D F F * N p(1-p)]}{[(\mathrm{d} 2 / \mathrm{Z} 21-\alpha / 2 *(\mathrm{~N}-1)+\mathrm{p} *(1-\mathrm{p})]}
$$

For a $95 \%$ confidence level, a sample of 335 participants was required. However, considering the possibility of losses and refusals, 30\% was added was added to this number, totaling 435 . Participants 
were selected through random drawing from the list of hypertensive and diabetic patients registered by the family health strategy teams, which was made available by the Municipal Health Department. Individuals who met the above-mentioned inclusion criteria and provided written informed consent were interviewed.

Data were collected through a structured questionnaire prepared by the author, which consisted of two sections. The first was collected sociodemographic data, ie, sex, age, marital status, income, education level, residence type, and the number of individuals in the household. The second was related to the medication and health service use, specifically the medications prescribed for SAH and/or $\mathrm{DM}$, where they were purchased, personal medication expenses, the use of private health insurance, the regularity of use in the 30 days prior to the interview, the services' infrastructure and office hours, the origin of the prescription/s, and the respondent's opinion about the access programs. To avoid recall bias, images of the RFM unit were used to identify the source. We also asked to see the prescription and/or medication packaging, which was possible in most cases. Data collection was preceded by a pilot study involving household interviews, which were applied by trained and supervised interviewers.

The medication sources for each respondent were classified as: public programs, ie, obtaining essential $\mathrm{SAH}$ and/or DM medications exclusively through one or more public access programs; private funds, ie, purchasing the medications through personal means; or a combination of public programs and private funds.

The medications were classified according to Anatomical Therapeutic Chemical Code. ${ }^{20}$ The fourth level (chemical subgroup) was used to classify antihypertensive and oral hypoglycemic medications and insulin.

This study was approved by the Federal University of Viçosa Human Research Ethics Committee (Opinion 3.189.435).

\section{Statistical analysis}

Variables were expressed as absolute and relative frequencies according to medication source. Pearson's chi-square test was used to compare user evaluations of the medication access programs. A 5\% significance level was used in the analyses. The data were analyzed in IBM SPSS Statistics 24.0 (IBM, Armonk, NY, USA).

\section{Results}

A total of 341 adults were interviewed, predominantly women aged at least 65 years (mean age 63.4 years; SD, 14.16). Most declared themselves to be non-White, lived in an urban area, did not live alone, lived in their own residence, and had a partner. Most participants were illiterate or had a low education level and their maximum income was $\leq 2$ times the federal minimum salary $(89.19 \%)$. Most respondents did not have private health insurance and only a fraction of those who did reported that their plan covered SAH and/or DM medications (Table 1).

A total of $70.68 \%(n=241)$ of the respondents had SAH alone, $11.14 \%(n=38)$ had DM alone, and $18.18 \%$ $(\mathrm{n}=62)$ had both. The prevalence of SAH (61.09\%) and DM (57.89\%) was higher among women.

A total of $82.67 \%$ of the hypertension medication and $88.61 \%$ of the oral hypoglycemic agents and insulin were provided by the RFM and/or SNTP. Women used more medications purchased with their own funds or from mixed sources than men. Most of those who purchased medications with their own funds were single, widowed, or divorced (55.26\%). More adults under 65 years of age exclusively used the RFM (56.86\%) and SNTP (52.63\%) to obtain medication than those who were 65 or older. More older adults and urban residents used medications obtained through mixed sources. The RFM was the main source for the majority of non-White and rural residents (Table 2).

Most of the SNTP users were women, aged between 45 and 64 years, non-White, urban residents, lived with a partner in their own residence, were illiterate or had incomplete primary education, and whose family income did not exceed the minimum salary (Table 2). RFM users were predominantly women, aged over 65 years, non-White, urban residents, lived with a partner in their own residence, were illiterate or had incomplete primary education, and had a family income 2 times the minimum salary (Table 2).

Regarding users who obtained medications from mixed sources, most were women aged 65 years or older, non-White, urban residents who lived with a partner in their own residence, were illiterate or had incomplete primary education, and had a family income $\leq 2$ times the minimum salary (Table 2). 


\begin{tabular}{|c|c|c|}
\hline \multirow{2}{*}{ Variable } & \multicolumn{2}{|c|}{ Users } \\
\hline & $\mathbf{n}$ & $\%$ \\
\hline Total & 341 & 100.00 \\
\hline \multicolumn{3}{|l|}{ Sex } \\
\hline Male & 125 & 36.87 \\
\hline Female & 214 & 63.13 \\
\hline \multicolumn{3}{|l|}{ Age range (years) } \\
\hline 18 to 44 & 34 & 10.06 \\
\hline 45 to 64 & 134 & 39.64 \\
\hline 65 or older & 170 & 50.30 \\
\hline \multicolumn{3}{|l|}{ Race } \\
\hline White & 112 & 33.04 \\
\hline Non-White & 227 & 66.96 \\
\hline \multicolumn{3}{|l|}{ Residence } \\
\hline Rural & 112 & 32.84 \\
\hline Urban & 229 & 67.16 \\
\hline \multicolumn{3}{|l|}{ Lives alone } \\
\hline Yes & 30 & 8.80 \\
\hline No & 311 & 91.20 \\
\hline \multicolumn{3}{|l|}{ Type of residence } \\
\hline Own house/apartament & 298 & 87.65 \\
\hline Other & 42 & 12.35 \\
\hline \multicolumn{3}{|l|}{ Marital status } \\
\hline Married/cohabiting & 218 & 63.93 \\
\hline Single/divorced/widowed & 123 & 36.07 \\
\hline \multicolumn{3}{|l|}{ Education level } \\
\hline Illiterate or incomplete Elementary School & 304 & 89.94 \\
\hline Complete Elementary School or Incomplete High School & 12 & 3.55 \\
\hline Complete High School or Incomplete Higher Education & 12 & 3.55 \\
\hline Complete higher education & 10 & 2.96 \\
\hline \multicolumn{3}{|l|}{ Family income } \\
\hline$\leq 1$ times the federal minimum salary ${ }^{*}$ & 139 & 41.74 \\
\hline$>1$ and $\leq 2$ the minimum salary & 158 & 47.45 \\
\hline$>2$ the minimum salary & 36 & 10.81 \\
\hline \multicolumn{3}{|l|}{ Private health insurance } \\
\hline Yes & 30 & 9.17 \\
\hline No & 297 & 90.83 \\
\hline \multicolumn{3}{|l|}{ Medications covered by private health insurance } \\
\hline Yes & 1 & 3.45 \\
\hline No & 28 & 96.55 \\
\hline \multicolumn{3}{|c|}{$\begin{array}{l}N \text { may vary due to missing data: sex }(n=339) \text {, age group }(n=338) \text {, race }(n=339) \text {, education }(n=338) \text {, family income }(n=333) \text {, has health insurance }(n=327) \text {, } \\
\text { medication covered by private health insurance }(n=29) \text {. } \\
\text { "As of } 2019 \text {, the federal minimum salary was } R \$ 998.00 / \text { month. }\end{array}$} \\
\hline
\end{tabular}




\begin{tabular}{|c|c|c|c|c|c|c|c|c|c|c|}
\hline \multirow{3}{*}{ Variable } & \multicolumn{6}{|c|}{ Public programs } & \multirow{2}{*}{\multicolumn{2}{|c|}{$\begin{array}{c}\text { Private funds } \\
\begin{array}{l}\text { Purchased with } \\
\text { private funds }\end{array}\end{array}$}} & \multirow{2}{*}{\multicolumn{2}{|c|}{$\begin{array}{c}\begin{array}{c}\text { Public programs } \\
\text { private funds }\end{array} \\
\text { Mixed sources }\end{array}$}} \\
\hline & \multicolumn{2}{|c|}{ *SNTP } & \multicolumn{2}{|c|}{ tRFM } & \multicolumn{2}{|c|}{ SNTP+RFM } & & & & \\
\hline & $\mathbf{n}$ & $\%$ & $\mathbf{n}$ & $\%$ & $\mathbf{n}$ & $\%$ & $\mathbf{n}$ & $\%$ & $\mathbf{n}$ & $\%$ \\
\hline \multicolumn{11}{|l|}{ Sex } \\
\hline Female & 90 & 58.82 & 22 & 59.46 & 31 & 63.27 & 27 & 71.05 & 44 & 70.97 \\
\hline Male & 63 & 41.18 & 15 & 40.54 & 18 & 36.73 & 11 & 28.95 & 18 & 29.03 \\
\hline \multicolumn{11}{|l|}{ Age range (years) } \\
\hline 18 to 44 & 17 & 11.11 & 5 & 13.16 & 4 & 8.51 & 3 & 7.89 & 5 & 8.06 \\
\hline 45 to 64 & 70 & 45.75 & 15 & 39.47 & 21 & 44.68 & 13 & 34.21 & 15 & 24.19 \\
\hline 65 or older & 66 & 43.14 & 18 & 47.37 & 22 & 46.81 & 22 & 57.89 & 42 & 67.74 \\
\hline \multicolumn{11}{|l|}{ Race } \\
\hline White & 53 & 34.64 & 10 & 26.32 & 16 & 32.65 & 14 & 36.84 & 19 & 31.15 \\
\hline Non-White & 100 & 65.36 & 28 & 73.68 & 33 & 67.35 & 24 & 63.16 & 42 & 68.85 \\
\hline \multicolumn{11}{|l|}{ Residence } \\
\hline Rural & 60 & 38.96 & 18 & 47.37 & 11 & 22.45 & 11 & 28.95 & 12 & 19.35 \\
\hline Urban & 94 & 61.04 & 20 & 52.63 & 38 & 77.55 & 27 & 71.05 & 50 & 80.65 \\
\hline \multicolumn{11}{|l|}{ Type of residence } \\
\hline Own house/apartament & 138 & 90.20 & 31 & 81.58 & 41 & 83.67 & 34 & 89.47 & 54 & 87.10 \\
\hline Other & 15 & 9.80 & 7 & 18.42 & 8 & 16.33 & 4 & 10.53 & 8 & 12.90 \\
\hline \multicolumn{11}{|l|}{ Lives alone } \\
\hline Yes & 17 & 11.04 & 2 & 5.26 & 1 & 2.04 & 4 & 10.53 & 6 & 9.68 \\
\hline No & 137 & 88.96 & 36 & 94.74 & 48 & 97.96 & 34 & 89.47 & 56 & 90.32 \\
\hline \multicolumn{11}{|l|}{ Marital status } \\
\hline Married/cohabiting & 103 & 66.88 & 23 & 60.53 & 37 & 75.51 & 17 & 44.74 & 38 & 61.29 \\
\hline Single/divorced/widowed & 51 & 33.12 & 15 & 39.47 & 12 & 24.49 & 21 & 55.26 & 24 & 38.71 \\
\hline \multicolumn{11}{|l|}{ Education level } \\
\hline Illiterate or incomplete Elementary School & 139 & 90.85 & 33 & 86.84 & 47 & 95.92 & 35 & 94.59 & 50 & 81.97 \\
\hline $\begin{array}{l}\text { Complete Elementary School or } \\
\text { Incomplete High School }\end{array}$ & 4 & 2.61 & 2 & 5.26 & 1 & 2.04 & 1 & 2.70 & 4 & 6.56 \\
\hline $\begin{array}{l}\text { Complete High School or Incomplete } \\
\text { Higher Education }\end{array}$ & 7 & 4.58 & 0 & 0.00 & 0 & 0.00 & 1 & 2.70 & 4 & 6.56 \\
\hline Complete higher education & 3 & 1.96 & 3 & 7.89 & 1 & 2.04 & 0 & 0.00 & 3 & 4.92 \\
\hline \multicolumn{11}{|l|}{ Family income } \\
\hline$\leq 1$ times the minimum salary ${ }^{* * *}$ & 73 & 48.99 & 10 & 27.03 & 20 & 41.67 & 10 & 26.32 & 26 & 42.62 \\
\hline$>1$ and $\leq 2$ times the minimum salary & 61 & 40.94 & 25 & 67.57 & 25 & 52.08 & 21 & 55.26 & 26 & 42.62 \\
\hline$>2$ times the minimum salary & 15 & 10.07 & 2 & 5.41 & 3 & 6.25 & 7 & 18.42 & 9 & 14.75 \\
\hline $\begin{array}{l}\text { N may vary due to the presence of missing data: sex } \\
\text { ( } n=327) \text {, medication covered by private health inst } \\
{ }^{*} \text { SNTP: Health Has No Price program and }+ \text { RFM } \\
* * * \text { As of } 2019 \text {, the federal minimum salary was } R \$\end{array}$ & Ainas & $\begin{array}{l}\text { age grou } \\
\text { 29). } \\
\text { armacy } 1 \\
\text { nth. }\end{array}$ & $\begin{array}{l}n=33 \\
\text { woork }\end{array}$ & ace $(n=$ & & $\operatorname{tion}(n=$ & famil & ie $(n=33$ & ivate h & surance \\
\hline
\end{tabular}


On the other hand, those who exclusively purchased medications with their own funds were predominantly women, aged 65 years or older, nonWhite, urban residents who lived with a partner in their own residence, were illiterate or had incomplete primary education, and had a family income 2 times the minimum salary (Table 2).

Table 3 shows the most common drug groups used by the respondents according to the Anatomical Therapeutic Chemical Classification System (4th level: chemical subgroup). The most common $\mathrm{SAH}$ medications were agents acting on the renin- angiotensin system, followed by diuretics and betablockers. The most common chemical subgroup of DM medications was biguanides. Agents such as sulfonylureas and insulin were also common (Table 3).

General user perception was significantly better for the SNTP program, with most rating it as excellent or very good. Regarding transportation, the percentage of patients who used public transportation was higher in the RFM program, while the percentage who used a car or motorcycle was higher in the SNTP program. Most of the SNTP users reported not waiting for assistance, although only a minority said the same Table 3 - Distribution of systemic arterial hypertension and diabetes mellitus medications used by respondents from a
small municipality in the Zona da Mata region of Minas Gerais, Brazil, 2019.

\begin{tabular}{|c|c|c|c|}
\hline \multirow{2}{*}{ ATC code } & \multirow{2}{*}{ Group and subgroup } & \multicolumn{2}{|c|}{ Total } \\
\hline & & $\mathbf{n}$ & $\%$ \\
\hline$C^{*}$ & CARDIOVASCULAR SYSTEM & 621 & 100.00 \\
\hline $\mathrm{C} 09+$ & Agents acting on the renin-angiotensin system & 243 & 39.13 \\
\hline C09AA & ACE inhibitors, isolated & 85 & 13.69 \\
\hline C09CA & Angiotensin II antagonists, isolated & 158 & 25.44 \\
\hline $\mathrm{C} 03+$ & Diuretics & 235 & 37.84 \\
\hline C03DAf & Aldosterone antagonists & 26 & 4.19 \\
\hline C03AA & Thiazides, isolated & 158 & 25.44 \\
\hline С03СA & Sulfonamides, isolated & 51 & 8.21 \\
\hline $\mathrm{C} 07+$ & Beta-blockers & 84 & 13.53 \\
\hline $\mathrm{C} 07 \mathrm{AB} \ddagger$ & Beta-adrenergic receptor blockers & 50 & 7.41 \\
\hline C07AG $\ddagger$ & Alpha- and beta-adrenergic receptor blockers & 16 & 2.58 \\
\hline C07AA & Non-selective beta-adrenergic receptor blockers & 18 & 2.90 \\
\hline $\mathrm{C} 08^{* *}$ & Calcium channel blockers & 46 & 7.41 \\
\hline C08CA & Dihydropyridine derivatives & 46 & 7.41 \\
\hline- & Others & 13 & 2.09 \\
\hline$A^{*}$ & ALIMENTARY TRACT AND METABOLISM & 158 & 100.00 \\
\hline $\mathrm{A} 10+$ & Drugs used in diabetes & 158 & 100.00 \\
\hline A10BA $\ddagger$ & Biguanides $\ddagger$ & 86 & 54.43 \\
\hline $\mathrm{A} 10 \mathrm{BB} \ddagger$ & Sulfonylureas $\ddagger$ & 42 & 26.58 \\
\hline A10AC $\ddagger$ & Intermediate-acting injectable insulins and analogues & 26 & 16.46 \\
\hline $\mathrm{A} 10 \mathrm{AB} \ddagger$ & Fast-acting injectable insulins and analogues & 4 & 2.53 \\
\hline
\end{tabular}


about the RFM. Finally, it should be pointed out that RFM users reported greater satisfaction (excellent/ very good) with the service's office hours (Table 4).

\section{Discussion}

This analysis of hypertensive and/or diabetic users of the SNTP and RFM medication access programs revealed that on-site studies can accurately describe the sociodemographic profile and medication use of clients according to demographic variables and health conditions, which can guide health interventions and public policies about access to medication. ${ }^{7,21}$ The sample in this municipality was predominantly women with $\mathrm{SAH}$, who acquired medication from a single source, primarily public programs. Most of the respondents lived in urban areas in their own house or apartment, which has been found in other national studies., ${ }^{78,21-23}$ However, most studies of this type have focused on urban populations, with few including both urban and rural populations. ${ }^{9,11,17,24-30}$

It can be inferred that, due to sociocultural and biological factors, women are more concerned with their health, take more medications, more regularly seek health services, and have more health programs specifically targeting them..$^{7,9,17,31-33}$ In our sample, women were more frequent users of public pharmaceutical assistance programs, which contrasts with the results of a study that analyzed data from the 2008 National Household Sample Survey. ${ }^{22}$

As has been observed in nationwide studies, $7,24,28,31$ most participants were aged 65 years or older, reported having a chronic disease, and had been prescribed medication. Medication access programs are intended for all citizens, regardless of age, but they play an important role in the lives of older adults, since they have greater health needs and use more medications. Programs that provide free access to medications can contribute to the control and prevention of chronic diseases. ${ }^{26}$

Regarding marital status, most of the respondents lived with a partner, which corroborates several other studies. ${ }^{11,17,36,37,21,26-29,32,34,35}$ Marital status can affect health service use, since married individuals seek health services more often, are more likely to receive a diagnosis and, consequently, obtain more information about and access to drug programs. ${ }^{26}$

Regarding education, most users were illiterate or had incomplete primary education, which is consistent with other Brazilian studies conducted in cities of all sizes. ${ }^{37,38}$
However, this differed from the findings of Costa et al. ${ }^{17}$ in the city of Campinas, São Paulo. According to Carvalho et al..$^{12}$ patients with low education can have difficulty understanding the prescribed treatment, as well as self-care. These results underscore the need for health education strategies to improve patient understanding of treatment, the rational use of medications, and the importance of pharmaceutical assistance programs, including pharmaceutical care. . $^{35,39}$

The family income of most respondents was low (ie, the federal minimum salary or less), which was similar to the results of studies conducted in Campinas ${ }^{27}$ and lower than that of small, medium, and large municipalities in the state of Pernambuco. ${ }^{31}$ National studies have shown that the costs of $\mathrm{CNCD}$ medications consume a large part of the income of poor patients and, without free access to medications, both the family budget and treatment can be compromised. ${ }^{40,41}$ We also found that most respondents with lower incomes acquire their CNCD medications through from the SNTP program, followed by mixed sources. Among respondents whose monthly income was at least 3 times the minimum salary, most acquired their medications through the SNTP, although a higher relative percentage also purchased medications with their own funds. This result indicates the need for further research to determine whether there is a positive association between user income and acquiring medications through their own funds. Tavares et al. ${ }^{1}$ pointed out that lowerincome groups had greater access to free medications for $\mathrm{CNCD}$, strengthening the hypothesis that, for this segment of the population, drug access programs were the main method of complying with pharmacological treatment (ie, compliance could be interrupted if it was necessary to purchase their medications with their own resources).

Costa et al. ${ }^{17}$ found that many people obtain at least one medication for SAH or DM through the SNTP, especially those with lower incomes. Boing et al. ${ }^{22}$ pointed out that most people who turn to the Unified Health System for medications have lower purchasing power, and that those with greater purchasing power finds it easier to obtain all of their CNCD medications through the private sector.

Helfer et al. ${ }^{41}$ reported that it would be desirable for $100 \%$ of CNCD medications to be available through the Unified Health System because, when they are not, users must purchase them with their own funds in drugstores, which can lead to treatment non-compliance due to the high cost. Thus, it is clear that Brazilian medication access programs play a fundamental role in minimizing 
Table 4 - Evaluation of medication access programs by patients with systemic arterial hypertension and/or diabetes mellitus in a small municipality in the Zona da Mata region of Minas Gerais, Brazil, 2019.

\begin{tabular}{|c|c|c|c|c|c|}
\hline \multirow{2}{*}{ Variable } & \multicolumn{2}{|c|}{ tSNTP } & \multicolumn{2}{|c|}{$\ddagger$ RFM } & \multirow[t]{2}{*}{$\mathrm{p}^{*}$} \\
\hline & $\mathbf{N}$ & $\%$ & $\mathbf{N}$ & $\%$ & \\
\hline \multicolumn{6}{|l|}{ Perception } \\
\hline Excellent/Very good & 144 & 51.99 & 43 & 37.07 & 0.010 \\
\hline Good & 115 & 41.52 & 58 & 50.00 & \\
\hline Average/Poor & 18 & 6.50 & 15 & 12.93 & \\
\hline \multicolumn{6}{|l|}{ Access } \\
\hline Not diffícult & 234 & 86.35 & 89 & 77.39 & 0.085 \\
\hline Slightly diffícult & 30 & 11.07 & 20 & 17.39 & \\
\hline Very diffícult & 7 & 2.58 & 6 & 5.22 & \\
\hline \multicolumn{6}{|l|}{ Means of transport } \\
\hline Pedestrian & 174 & 63.04 & 71 & 62.83 & 0.007 \\
\hline Bus/collective transport & 36 & 13.04 & 28 & 24.78 & \\
\hline Car, motorcycle, or boat & 48 & 17.39 & 11 & 9.73 & \\
\hline Other & 18 & 6.52 & 3 & 2.65 & \\
\hline \multicolumn{6}{|l|}{ Distant } \\
\hline Yes & 33 & 11.91 & 21 & 18.26 & 0.162 \\
\hline More or less & 34 & 12.27 & 17 & 14.78 & \\
\hline No & 210 & 75.81 & 77 & 66.96 & \\
\hline \multicolumn{6}{|l|}{ Waiting time } \\
\hline None & 181 & 65.34 & 42 & 37.17 & $<0.001$ \\
\hline Short & 90 & 32.49 & 60 & 53.10 & \\
\hline Long & 6 & 2.17 & 11 & 9.73 & \\
\hline \multicolumn{6}{|l|}{ Office hours } \\
\hline Excellent & 82 & 29.82 & 24 & 20.87 & $<0.001$ \\
\hline Very good & 48 & 17.45 & 84 & 73.04 & \\
\hline Good & 142 & 51.64 & 6 & 5.22 & \\
\hline Average & 3 & 1.09 & 1 & 0.87 & \\
\hline
\end{tabular}

inequality regarding antihypertensive and antidiabetic therapy. ${ }^{11,38,40}$

In the present study, most respondents declared themselves to be non-White. Similar racial findings have been observed by other authors, ${ }^{14,16,27,29}$ although other national studies ${ }^{23,25,42,43}$ have found a majority of Whites in their populations. The racial characteristics of our respondents pertain to a segment of the population that has historically been excluded from public policies and is socially more vulnerable, generally depending on free medication programs to comply with CNCD treatment. 22,35

Renin-angiotensin inhibitors were the most frequent SAH medication, followed by diuretics and beta blockers, 
which is similar to the results of other studies. ${ }^{7,27,34,44}$ The most frequent antihypertensive medications were also compatible with the VII Brazilian Guidelines on Hypertension: ${ }^{4}$ "disease control in initial monotherapy due to the reduction of cardiovascular events, lower incidence of adverse effects, and low cost". Furthermore, the Brazilian Unified Health System provides free medications in the vast majority of therapeutic classes used to treat $\mathrm{SAH}$, demonstrating that the pharmaceutical assistance cycle has been well executed by the government. ${ }^{8}$

The most common medications used to treat DM were biguanides, sulfonylureas and insulins, which is consistent with the results of other national studies. ${ }^{27,44}$ These medications agree with the therapeutic algorithm recommended in the Brazilian Diabetes Society guidelines. ${ }^{5}$ In general, oral antidiabetics are the first choice for treating type $2 \mathrm{DM}$, which affects the vast majority of people with diabetes, since they reduce complications arising from the disease, are well tolerated, easy to prescribe, and interfere less with body weight. ${ }^{2}$ However, type $2 \mathrm{DM}$ may also require insulin in some cases. Type $1 \mathrm{DM}$ treatment, on the other hand, always requires insulin. It is important to emphasize that non-pharmacological treatment is essential and includes lifestyle changes, such as healthy eating, physical activity, etc. ${ }^{2}$

According to Brazilian Diabetes Society guidelines, ${ }^{5}$ the choice of medication should be based on: DM type, the patient's age and general condition, obesity and comorbidities, fasting, postprandial, and $\mathrm{HbA} 1 \mathrm{c}$ blood glucose values, drug efficacy, the risk of hypoglycemia, possible interactions with other medications, adverse reactions, contraindications, cost, and patient preference.

In this study, $90.83 \%$ of the respondents did not have private health insurance, indicating that they benefit from public health services, which corroborates other studies on the subject. ${ }^{1,7,9,11,32,35,37,40,44}$ Costa et al. ${ }^{11}$ found that people without private health insurance more frequently use free medication programs, which shows that RFM and SNTP mainly serve those who depend exclusively on government health programs, as was observed in the present study. Moreover, we observed that the medication coverage provided by private insurance was insignificant, as was also reported by Pereira. $^{7}$

In our sample, rural residents obtained most of their medications through SNTP, followed by mixed sources, and RFM. For urban residents, however, the main sources were SNTP, followed by mixed sources, and their own funds. Other Brazilian studies ${ }^{22,23}$ have found that rural populations tend to procure $\mathrm{CNCD}$ medications through government programs. Access to private health services in rural areas is limited because this population generally has lower purchasing power. ${ }^{45}$

Most SNTP users in our sample reported no waiting time. Similar data were found by the National Survey on Access, Use and Promotion of Rational Use of Medicines (PNAUM) ${ }^{46}$ Possible explanations for the shorter waiting time at SNTP include more employees and higher level of automation. A minority said they did not wait to be seen at the RFM, which diverges from the findings of Barbosa et al. ${ }^{47}$ in Minas Gerais. The longer waiting time in the state program could be due to its larger list of medications, in addition to its directives regarding rational use, which includes pharmacotherapeutic monitoring, a practice that should not disregarded by SNTP. ${ }^{48}$ It is assumed that to improve user perception of public programs, they must understand that providing medications is not a mere act of product delivery, but rather a protocol that encompasses safety and rational use issues for their own well-being. In addition, constant investment in technology, human resources, and training are required to make access programs more efficient. ${ }^{49}$

Most of our respondents described the RFM office hours as excellent or very good. Other national studies have shown similar results, ${ }^{47}$ which contradicts the notion that opening health service after $6 \mathrm{pm}$ and on weekends would facilitate access. However, when evaluating Basic Health Units, Reis ${ }^{50}$ found that alternative hours are needed to provide care for economically active users.

One strength of the present study is its innovative character, since it determined the sociodemographic profile of medication access program users in both urban and rural areas. In addition, although Barbosa et al. ${ }^{47}$ assessed RFM waiting time, we could find no studies involving user evaluation of SNTP office hours or waiting time and no studies comparing the RFM and SNTP for these indicators. Likewise, we could find no other studies that compared medication sources between rural and urban populations.

Restricting the sample to a single municipality was a limiting factor. Likewise, the 30-day recall regarding medication sources and consumption patterns could 
be considered a methodological limitation, since the respondents, especially the older ones, might have had difficulty remembering. To avoid recall bias, images of the RFM unit were shown during the interview help to identify the source, and we asked the respondents to show us their prescriptions and/or medication packaging, which they did in most cases. Another limitation was that we did not include non-users of medication access programs as a control group.

\section{Conclusions}

The results of this study indicate that essential medication access programs are important sources of $\mathrm{SAH}$ and DM medications and serve different strata of the studied population. These programs promote equity and universality in health care in both urban and rural areas. By providing medication access to socially and economically vulnerable populations, they reduce class and regional inequalities.

It was clear that investigating user satisfaction with these programs is also relevant, since user feedback is essential to improving pharmaceutical assistance and guiding strategic and operational decisions that influence the quality and continuity of pharmaceutical services.

The pharmacist's role in the multidisciplinary team should also be highlighted, since it is important in expanding access to medications by providing clinical services, such as pharmaceutical care. Considering that the majority of our sample was illiterate or had a low education level, educational programs and health promotion are essential for guaranteeing the rational use of medications and improving the population's quality of life.

\section{References}

1. Tavares NUL, Luiza VL, Oliveira MA, Costa KS, Mengue SS, Arrais PSD, et al. Free access to drugs for the treatment of chronic diseases in Brazil. Rev Saude Publica. 2016;50(Suppl 2):7s. https://doi.org/10.1590/ s1518-8787.2016050006118.

2. Brasil. Ministério da Saúde. Secretaria de Atenção à Saúde. Departamento de Atenção Básica. Estratégias para o cuidado da pessoa com doença crônica : diabetes mellitus. Brasília; 2013.

3. Malta DC, Gonçalves RPF, Machado ÍE, Freitas MI de F, Azeredo C, Szwarcwald CL. Prevalência da hipertensão arterial segundo diferentes critérios diagnósticos, Pesquisa Nacional de Saúde. Rev Bras Epidemiol 2018;21(supl 1):1-15. https://doi.org/10.1590/1980-549720180021.supl.1.

4. Malachias M, Souza W, Plavnik F, Rodrigues C, Brandão A, Neves M, et al. Capítulo 1 - Conceituação, Epidemiologia e Prevenção Primária. Arq Bras Cardiol. 2016;107(3 supl3):1-6. https://doi.org/10.5935/abc.20160151.
However, additional studies are needed in other small municipalities to corroborate our findings and to better determine the profile of these patients, which can lead to more effective health strategies and public policies.

\section{Author contributions}

Conception and design of the research: Chaves ZJL, Silva LS, Nascimento, RCRM. Acquisition of data: Chaves ZJL. Analysis and interpretation of the data: Chaves ZJL, Silva LS, Nascimento RCRM. Writing of the manuscript: Chaves ZJL. Critical revision of the manuscript for intellectual content: Silva LS, Nascimento RCRM .

\section{Potential Conflict of Interest}

No potential conflict of interest relevant to this article was reported.

\section{Sources of Funding}

There were no external funding sources for this study.

\section{Study Association}

This article is part of the thesis of master submitted by Zeó Jaime Lacerda Chaves, from Universidade Federal de Viçosa.

\section{Ethics approval and consent to participate}

This study was approved by the Ethics Committee of the Universidade Federal de Viçosa under the protocol number 3.189.435. All the procedures in this study were in accordance with the 1975 Helsinki Declaration, updated in 2013. Informed consent was obtained from all participants included in the study.

5. Sociedade Brasileira de Diabetes. Diretrizes da Sociedade Brasileira de Diabetes: 2019-2020. São Paulo: Clannad Editora Científica; 2019.

6. International Diabetes Federation. IDF Diabetes Atlas. 8th ed Belgium; 2017.

7. Pereira VO de M, Acurcio F de A, Guerra Júnior AA, Silva GD da, Cherchiglia ML. Perfil de utilização de medicamentos por indivíduos com hipertensão arterial e diabetes mellitus em municípios da Rede Farmácia de Minas. Cad Saude Publica .2012;28(8):1546-58. https://doi. org/10.1590/S0102-311X2012000800013.

8. Oliveira MA, Luiza VL, Tavares NUL, Mengue SS, Arrais PSD, Farias MR, et al. Access to drugs for chronic diseases in Brazil: a multidimensional approach. Rev Saude Publica. 2016;50(Suppl 2):6s. https://doi. org/10.1590/s1518-8787.2016050006161. 
9. Matta SR, Bertoldi AD, Emmerick ICM, Fontanella AT, Costa KS, Luiza VL. Fontes de obtenção de medicamentos por pacientes diagnosticados com doenças crônicas, usuários do Sistema Único de Saúde. Cad Saude Publica 2018;34(3):200073817. https://doi.org/10.1590/0102$311 \times 00073817$.

10. Garcia MM, Guerra Júnior AA, Acúrcio F de A. Avaliação econômica dos Programas Rede Farmácia de Minas do SUS versus Farmácia Popular do Brasil. Cien Saude Colet 2017;22(1):221-33. https://doi.org/10.1590/141381232017221.15912015 .

11. Costa KS, Francisco PMSB, Barros MB de A. Conhecimento e utilização do Programa Farmácia Popular do Brasil: estudo de base populacional no município de Campinas-SP. Epidemiol e Serviços Saúde 2014;23(3):397_ 408. https://doi.org/10.5123/S1679-49742014000300003.

12. Carvalho TP de, Okuno MFP, Campanharo CRV, Lopes MCBT, Batista REA. Patients' knowledge about medication prescription in the emergency service. Rev Bras Enferm 2018;71(2):329-35. https://doi. org/10.1590/0034-7167-2017-0002.

13. Pereira DAD, Almeida, Vieira SA, Fogal AS, Ribeiro AQ, Franceschini $\mathrm{S}$ do CC. Aspectos metodológicos na construção de projetos de pesquisa em Nutrição Clínica. Rev Nutr. 2014;27:597-604. https://doi. org/10.1590/1415-52732014000500008.

14. Barbosa MR. Organização da assistência farmacêutica e acesso aos medicamentos na atenção primária do Sistema Único de Saúde: avaliação de uma política pública. Tese. Belo Horizonte (MG):Universidade Federal de Minas Gerais; 2018.

15. Santos-Pinto CDB, Costa N do R, Osorio-de-Castro CGS. Quem acessa o Programa Farmácia Popular do Brasil? Aspectos do fornecimento público de medicamentos. Cien Saude Colet. 2011;16:2963-73. https:// doi.org/10.1590/S1413-81232011000600034.

16. Nascimento RCRM do, Álvares J, Guerra Junior AA, Gomes IC, Costa EA, Leite SN, et al. Availability of essential drugs in primary health care of the Brazilian Unified Health System. Rev Saude Publica. 2017;51(Suppl 2):1s-11s. https://doi.org/10.11606/S1518-8787.2017051007062.

17. Costa KS, Barros MB de A, Francisco PMSB, César CLG, Goldbaum M, Carandina L. Utilização de medicamentos e fatores associados: um estudo de base populacional no Município de Campinas, São Paulo, Brasil. Cad Saude Publica . 2011;27(4):649-58. https://doi.org/10.1590/ S0102-311X2011000400004.

18. Instituto Brasileiro de Geografia e Estatística. IBGE - Cidades @ - Jequeri 2018. [Citado em 2020 jan 12]. Disponível em: https://cidades.ibge.gov. $\mathrm{br} / \mathrm{brasil} / \mathrm{mg} /$ jequeri/panorama (accessed June 14, 2021).

19. Instituto Brasileiro de Geografia e Estatística.(IBGE). Classificação e caracterização dos espaços rurais e urbanos do Brasil: uma primeira aproximação. Rio de Janeiro; 2017. [Citado em 2021 june 24]. Disponível em;https://biblioteca.ibge.gov.br/visualizacao/livros/liv100643.

20. World Health Organization. (WHO). Collaborating Centre for Drug Statistics Methodology. ATC/DDD Index. Geneva:World Health Organ; 2019.

21. Arrais PSD, Brito LL, Barreto ML, Coelho HLL. Prevalência e fatores determinantes do consumo de medicamentos no Município de Fortaleza, Ceará, Brasil. Cad Saude Publica; 2005;21(6):1737-46. https://doi. org/10.1590/S0102-311X2005000600021.

22. Boing AC, Bertoldi AD, Boing AF, Bastos JL, Peres KG. Acesso a medicamentos no setor público: análise de usuários do Sistema Único de Saúde no Brasil. Cad Saude Publica 2013;29:691-701. https://doi. org/10.1590/S0102-311X2013000400007.

23. Katrein F, Tejada CAO, Restrepo-Méndez MC, Bertoldi AD. Desigualdade no acesso a medicamentos para doenças crônicas em mulheres brasileiras. Cad Saude Publica 2015;31(7):1416-26. https://doi.org/10.1590/0102$311 X 00083614$.

24. Bertoldi AD, Pizzol T da SD, Ramos LR, Mengue SS, Luiza VL, Tavares NUL, et al. Sociodemographic profile of drug users in Brazil: results from the 2014 PNAUM survey. Rev Saude Publica. 2016;50(Suppl 2):5s. https://doi.org/10.1590/s1518-8787.2016050006119.
25. Aziz MM, Calvo MC, Schneider IJC, Xavier AJ, D’Orsi E. Prevalência e fatores associados ao acesso a medicamentos pela população idosa em uma capital do sul do Brasil: um estudo de base populacional. Cad Saude Publica. 2011;27(10):1939-50. https://doi.org/10.1590/ S0102-311X2011001000007.

26. Miranda VIA, Fassa AG, Meucci RD, Lutz BH. Use of the Brazilian People's Pharmacy Program by older adults. Rev Saude Publica . 2016;50:13. https://doi.org/10.1590/S1518-8787.2016050006180.

27. Prado MAMB do, Francisco PMSB, Barros MB de A. Diabetes em idosos: uso de medicamentos e risco de interação medicamentosa. Cien Saude Colet. 2016;21(11):3447-58. https://doi.org/10.1590/1413812320152111.24462015 .

28. Fleith VD, Figueiredo MA, Figueiredo KFLRDO, Moura EC. Perfil de utilização de medicamentos em usuários da rede básica de saúde de Lorena, SP. Cien Saude Colet 2008;13(Suppl):755-62. https://doi. org/10.1590/S1413-81232008000700026.

29. Vosgerau MZ da S, Soares DA, Souza RKT de, Matsuo T, Carvalho $\mathrm{G}$ dos S. Consumo de medicamentos entre adultos na área de abrangência de uma Unidade de Saúde da Família. Cien Saude Colet. 2011;16(Suppl 1):1629-38. https://doi.org/10.1590/S141381232011000700099 .

30. Gontijo M de F, Ribeiro AQ, Klein CH, Rozenfeld S, Acurcio F de A. Uso de anti-hipertensivos e antidiabéticos por idosos: inquérito em Belo Horizonte, Minas Gerais, Brasil. Cad Saude Publica. 2012;28(7):1337-46. https://doi.org/10.1590/S0102-311X2012000700012.

31. Barreto MNS de C, Cesse EÂP, Lima RF, Marinho MG da S, Specht $\mathrm{Y}$ da S, Carvalho EMF de, et al. Analysis of access to hypertensive and diabetic drugs in the Family Health Strategy, State of Pernambuco, Brazil. Rev Bras Epidemiol. 2015;18(2):413-24. https:// doi.org/10.1590/1980-5497201500020010.

32. Leitão VBG, Lemos VC, Francisco PMSB, Costa KS. Prevalência de uso e fontes de obtenção de medicamentos anti-hipertensivos no Brasil: análise do inquérito telefônico VIGITEL. Rev Bras Epidemiol. 2020;23:e200028 . https://doi.org/10.1590/1980-549720200028.

33. Salvador EP, Florindo AA, Reis RS, Costa EF. Percepção do ambiente e prática de atividade física no lazer entre idosos. Rev Saude Publica. 2009;43(6):972-80. https://doi.org/10.1590/S0034-89102009005000082.

34. Galato D, Silva ES da, Tiburcio L de S. Estudo de utilização de medicamentos em idosos residentes em uma cidade do sul de Santa Catarina (Brasil): um olhar sobre a polimedicação. Cien Saude Colet. 2010;15(6):2899-905. https://doi.org/10.1590/S141381232010000600027.

35. Costa KS, Francisco PMSB, Malta DC, Barros MB de A. Fontes de obtenção de medicamentos para hipertensão e diabetes no Brasil: resultados de inquérito telefônico nas capitais brasileiras e no Distrito Federal, 2011. Cad Saude Publica .2016;32(2):e00090014. https://doi. org/10.1590/0102-311X00090014.

36. Mengue SS, Bertoldi AD, Ramos LR, Farias MR, Oliveira MA, Tavares NUL, et al. Access to and use of high blood pressure medications in Brazil. Rev Saude Publica .2016;50(Suppl 2):6s. https://doi.org/10.1590/ s1518-8787.2016050006154.

37. Luz TCB, Loyola Filho AI de, Lima-Costa MF. Estudo de base populacional da subutilização de medicamentos por motivos financeiros entre idosos na Região Metropolitana de Belo Horizonte, Minas Gerais, Brasil. Cad Saude Publica. 2009;25(7):1578-86. https:// doi.org/10.1590/S0102-311X2009000700016.

38. Costa CMFN, Silveira MR, Acurcio F de A, Guerra Junior AA, Guibu IA, Costa KS, et al. Use of drugs by patients of the primary health care of the Brazilian Unified Health System. Rev Saude Publica. 2017;51(Suppl 2):1s-11s https://doi.org/10.11606/S15188787.2017051007144.

39. Ruppenthal LR, Petrovick PR. Comparação do perfil dos usuários e dos medicamentos dispensados na farmácia popular do Brasil e em drogaria privada em Porto Alegre, Brasil. Lat Am J Pharm. 2010;29(1):22-9. 
40. Monteiro CN, Lima MG, Szwarcwald CL, Bastos TF, Barros MB de A. Utilização de anti-hipertensivos e antidiabéticos no Brasil: análise das diferenças socioeconômicas. Pesquisa Nacional de Saúde 2013. Rev Bras Epidemiol. 2019;22(2):E190014. https://doi.org/10.1590/1980549720190014.supl.2.

41. Helfer AP, Camargo AL, Tavares NUL, Kanavos P, Bertoldi AD. Capacidade aquisitiva e disponibilidade de medicamentos para doenças crônicas no setor público. Rev Panam Salud Pública 2012;31(3):225-32. https://doi.org/10.1590/S1020-49892012000300007.

42. Monteiro CN, Gianini RJ, Barros MB de A, Cesar CLG, Goldbaum M. Access to medication in the Public Health System and equity: populational health surveys in São Paulo, Brazil. Rev Bras Epidemiol 2016;19(1):26-37. https://doi.org/10.1590/1980-5497201600010003.

43. Stopa SR, Cesar CLG, Segri NJ, Alves MCGP, Barros MB de A, Goldbaum M. Prevalência da hipertensão arterial, do diabetes mellitus e da adesão às medidas comportamentais no Município de São Paulo, Brasil, 2003-2015. Cad Saude Publica .2018;34(10):e00198717. https://doi.org/10.1590/0102311x00198717.

44. Silva MRR da, Diniz LM, Santos JBR, Reis EA, Mata AR da, Araújo VE de, et al. Uso de medicamentos e fatores associados à polifarmácia em indivíduos com diabetes mellitus em Minas Gerais, Brasil. Cien Saude Colet. 2018;23(8):2565-74. https://doi.org/10.1590/141381232018238.10222016

45. Arruda NM, Maia AG, Alves LC. Desigualdade no acesso à saúde entre as áreas urbanas e rurais do Brasil: uma decomposição de fatores entre 1998 a 2008. Cad Saude Publica.2018;34(6): e00213816 https://doi. org/10.1590/0102-311x00213816.

46. Leite SN, Bernardo NLM da C, Álvares J, Guerra AA, Costa EA, Acurcio $\mathrm{F}$ de A, et al. Medicine dispensing service in primary health care of SUS. Rev Saude Publica. 2017;51(Suppl 2):11s. https://doi.org/10.11606/S15188787.2017051007121.

47. Barbosa MM, Garcia MM, Nascimento RCRM do, Reis EA, Guerra Junior AA, Acurcio F de A, et al. Avaliação da infraestrutura da Assistência Farmacêutica no Sistema Único de Saúde em Minas Gerais. Cien Saude Colet. 2017;22(8):2475-86. https://doi.org/10.1590/141381232017228.10952017.

48. Minas Gerais. Secretaria de Estado de Saúde. Rede farmácia de Minas: plano estadual de estruturação da rede de assistência farmacêutica: uma estratégia para ampliar o acesso e o uso racional de medicamentos no SUS. Belo Horizonte; 2008.

49. Casali A, Bandeira V, Schneider A, Barden Schallemberger J, Codinotti M, Uecker Pletsch M, et al. Avaliação da satisfação dos usuários das farmácias do sistema público de saúde. Rev Bras Em Promoção Da Saúde 2017;30(3):1-8. https://doi.org/10.5020/18061230.2017.6193.

50. Reis RS, Coimbra LC, Silva AAM da, Santos AM dos, Alves MTSS de B e, Lamy ZC, et al. Acesso e utilização dos serviços na Estratégia Saúde da Família na perspectiva dos gestores, profissionais e usuários. Cien Saude Colet. 2013;18(11):3321-31. https://doi.org/10.1590/S141381232013001100022 . 